\title{
Programming Mahler: Meaning, Re-description, and the Post-Adornian Counterlife
}

\author{
Jeremy Barham \\ University of Surrey \\ Email: j.barham@surrey.ac.uk
}

\begin{abstract}
In this article Adorno's approach to Mahler is subjected to linguistic-conceptual critique, in order to highlight its ambiguous philosophical and methodological syncretizing of discourses of epistemological commensurability and hermeneutic incommensurability. As a response to this and to Adorno's privileging of authorial production as determinant of meaning, this study invokes Richard Rorty's pragmatist philosophy and aspects of translation theory in order better to understand the world of post-Adornian Mahlerian meaning generated by use of the music in diverse screen works over the last half century. Examples of the 're-description' of Mahler's music resulting from such usage are discussed in relation to the tradition spawned by Visconti's Death in Venice and in various contexts of appropriation, fragmentation and juxtaposition through which radical re-configurations of putative meaning take place.
\end{abstract}

Life is and: the accidental and the immutable, the elusive and the graspable, the bizarre and the predictable, the actual and the potential, all the multiplying realities, entangled, overlapping, colliding, conjoined - plus the multiplying illusions! ... Is an intelligent human being likely to be much more than a largescale manufacturer of misunderstanding? ${ }^{1}$

Vera Micznik has done more than most Mahler scholars in expertly unpicking the theoretical substructure of discussions of meaning, programmes, and the axis of poietic and aesthesic levels associated with the composer's music. ${ }^{2}$ Yet at the end of her most recent study, she signs off by quoting a golden passage from near the beginning of Adorno's Mahler book that seems to undercut such theorizing, and

1 Philip Roth, The Counterlife [1986] (London: Vintage, 2005): 310.

2 See 'Is Mahler's Music Autobiographical? A Re-appraisal', Revue Mahler Review 1 (Feb. 1987): 47-63; 'Meaning in Gustav Mahler's Music: A Historical and Analytical Study Focussing on the Ninth Symphony' (PhD diss., State University of New York at Stony Brook, 1989); 'The Farewell Story of Mahler's Ninth Symphony', $19^{\text {th }}$-Century Music 20 (1996-7), 144-66; 'The Absolute Limitations of Programme Music: the Case of Liszt's Die Ideale', Music \& Letters 80 (1999): 207-40; 'Music and Narrative Revisited: Degrees of Narrativity in Beethoven and Mahler', Journal of the Royal Musical Association 126 (2001): 193-249; " "Ways of Telling" in Mahler's Music: The Third Symphony as Narrative Text' in Perspectives on Gustav Mahler, ed., Jeremy Barham (Aldershot: Ashgate, 2005): 295-323; 'Music and Aesthetics: the Programme Issue' in The Cambridge Companion to Mahler, ed., Jeremy Barham (Cambridge: Cambridge University Press, 2007): 35-48. 
moreover to challenge the 'plural textualities' and open-ended 'semiotic chains' she had previously been advocating in her text. The quoted section reads:

[Mahler] is particularly resistant to theorizing because he entirely fails to acknowledge the choice between technique and imaginative content. ... To understand him would be to endow with speech the music's structural elements while technically locating the glowing expressive intentions. Mahler can only be seen in perspective by moving still closer to him, by entering into the music and confronting the incommensurable presence that defies stylistic categories of program and absolute music ... Instead of illustrating ideas, [his symphonies] are destined concretely to become the idea. As each of their moments, tolerating no evasion into the approximate, fulfils its musical function, it becomes more than its mere existence: a script prescribing its own interpretation. ${ }^{3}$

Micznik earlier admits that it is 'important ... to ... argue why some programmatic readings are more plausible than others'. ${ }^{4}$ And both she and Adorno appear to be caught in the poststructuralist dilemma between a supposed anti-authoritarian and anti-authorial critical relativism on the one hand, and on the other, a hierarchical privileging of certain readings, such that in terms of a quasi-Orwellian doublethink, 'all interpretations are equal but some are more equal than others'. Immediately after the above-quoted passage, Adorno continues:

The curves so enjoined are to be traced by contemplation, rather than by ratiocination on the music from an ostensibly fixed standpoint external to it, in the pharisaic manner of the 'New Objectivity', tirelessly toying with clichés such as that of the titanic late Romantic. ${ }^{5}$

Furthermore, Micznik's two ellipses omit, among other things, the following phrases in Adorno's text:

In his work a purely musical residue stubbornly persists that can be interpreted in terms neither of processes nor of moods. ${ }^{6}$

3 Theodor W. Adorno, Mahler: A Musical Physiognomy, trans. Edmund Jephcott (Chicago: The University of Chicago Press, 1992): 4, cited in Micznik, 'Music and Aesthetics', 48. Mahler aber ist darum gegen das theoretische Wort besonders spröde, weil er der Alternative von Technologie und Vorstellungsgehalt überhaupt nicht gehorcht. ... Ihn verstünde, wer die musikalischen Strukturelemente zum Sprechen brächte, die aufblitzenden Intentionen des Ausdrucks aber technisch lokalisierte. Mahler ist in Perspektive nur dadurch zu rücken, daß man noch näher an ihn heran, daß man in ihn hineingeht und dem Inkommensurabeln sich stellt, das der Stilkategorien programmatischer und absoluter Musik ebenso spottet ... . Anstatt Ideen zu illustrieren, ist sie [seine Symphonik] konkret zur Idee bestimmt. Indem ein jeglicher ihrer Augenblicke, ohne Ausweichen ins Ungefähre zu dulden, seine kompositorischen Funktion genügt, wird er mehr also sein bloßes Dasein; eine Schrift, welche die eigene Deutung vorschreibt. Mahler: Eine musikalische Physiognomik (Frankfurt: Suhrkamp Verlag, 1960): 9-10.

4 'Music and Aesthetics', 47.

5 Mahler: A Musical Physiognomy, 4. Die Kurven solcher Nötigung sind betrachtend nachzuzeichnen, anstatt daß über die Musik von einen ihr äußerlichen, vermeintlich fixen Standpunkt aus räsoniert würde wie dem neusachlichen Pharisäismus, der unverdrossen mit Clichés wie dem vom titatenhaften Spätromantiker herumwürfelt. Mahler: Eine musikalische Physiognomik, 10.

6 Mahler: A Musical Physiognomy, 3. Bei ihm behauptet im Reinmusikalischen hartnäckig sich ein Rest, der doch weder auf Vorgänge noch auf Stimmungen zu interpretieren ware. Mahler: Eine musikalische Physiognomik, 10. 
and:

His symphonies assist such closeness by the compelling spirituality of their sensuous musical configurations. ${ }^{7}$

On the one hand, then, Adorno denies access to the interpretation of Mahler's music through rational analysis and objectivity in favour of 'contemplation', but on the other hand, he suggests that Mahler's symphonic content tolerates 'no evasion into the approximate' and provides 'a script prescribing its own interpretation'. The key to this paradox would seem to lie first in the distinction Adorno makes between music 'becoming' a concrete idea as opposed to merely 'illustrating' ideas, and second, by contrast, his blurring of the distinction within criticism between imagination and inference, the twin philosophical poles of hermeneutic and epistemological inquiry. ${ }^{8}$ Just as significantly, the sentences omitted by Micznik intimate the existence of a profound spiritual dimension in Mahler's music that emanates from its physical attributes but nevertheless defies definition. The reason this approach is paradoxical, or at least confusing, is that, through his allusion-drenched phraseology, Adorno appears to be invoking different philosophical systems to frame his thinking. What is more, Edmund Jephcott's translation, on which Micznik's article is drawing, tends to exacerbate this uncertainty through an occasional softening of tone and subtle reinterpretation of syntax. This is not to find fault with Jephcott's heroic translation, but rather to highlight the perennial difficulties of the act of translation itself - made no easier in this case by Adorno's complex and figurative prose style. These ambiguities demonstrate how simple vocabulary and context issues are inextricably linked to deeper and more complex conceptual questions.

For example, in the sentence: 'Ihn verstünde, wer die musikalischen Strukturelemente zum Sprechen brächte, die aufblitzenden Intentionen des Ausdrucks aber technisch lokalisierte', 'aufblitzenden' has been translated as 'glowing', which, although one of the word's possible meanings, does not capture the full implication of its root, 'Blitz' ('lightning'). ${ }^{9}$ The widely known figurative meaning of 'aufblitzen' is 'to flash', 'to gleam suddenly', or to 'glance like lightning', and this has been most commonly associated with the notion of thoughts flashing across the mind. This distinction is not mere pedantry, for it seems that there is likely a strong sense of the involuntary, the unbidden and the inspirational in what Adorno is saying about Mahler's 'expressive intentions'. Indeed this is precisely how the word is used by Nietzsche (whose writings constituted one of the formative influences on Adorno's thinking) in his self-reflections on the origins and content of Also sprach Zarathustra found in Ecce Homo. In a discussion of the role of inspiration, Nietzsche writes:

One hears, one does not seek; one accepts, one does not ask who gives; like lightning, a thought flashes up, with necessity, without hesitation regarding its

7 Mahler: A Musical Physiognomy, 4. Seine Symphonik hilft dazu durch die zwingende Spiritualität ihrer sinnlich-musikalischen Konfigurationen. Mahler: Eine musikalische Physiognomik, 10.

8 See Richard Rorty, Philosophy and the Mirror of Nature (Oxford: Blackwell, 1980): 315-56.

9 One of the meanings of 'Aufblitzen', a literal one, is the same as one of the meanings of 'Aufblicken', which is used in metallurgy to describe the glowing or brightening of a metal. 
form-I never had any choice. ... Everything happens involuntarily, in the highest degree but as in a gale of a feeling of freedom, of absoluteness, of power, of divinity. ${ }^{10}$

The dialectical paradox - somewhat concealed in the English - between 'unfreiwillig' (implying the determining of something independently of one's will, possibly by a 'higher force') and 'Freiheitsgefühl' (suggesting the impression of a personally felt context of freedom) is precisely that which Adorno expresses in his linguistic formulation of the (uncontrolled) 'flashing like lightning' of the (controlled) 'expressive intentions' in Mahler's music, that are to be 'technically located', but only through 'contemplation', on a wave of Nietzschean 'divine power', for which we may read Adorno's Mahlerian 'compelling spirituality'. This dialectic also characterizes Adorno's almost biblical counterpoising of the following two oppositional groups of terms and statements (some offered here with alternative translations):

\section{A. Commensurability and inference}

- Mahler's symphonism 'destined concretely' (as opposed to - in philosophical terms - abstractly) 'to become the idea' (or, more literally, to be 'defined' or 'ordained as Idea' in the sense of 'the word made flesh')

- the musical elements not 'tolerating' approximation (translatable just as accurately, but more strongly, as not 'permitting')

- each moment of the music becoming 'more than its mere existence' (the use of 'Dasein' inevitably evoking a critique of Heideggerian ahistorical, immediate presence or being $)^{11}$

- the script's 'prescribed' meaning (more strongly: 'dictated' or 'commanded')

- the 'enjoined' contours of this meaning (more strongly: 'forced', 'compelled')

- the 'tracing' (that is, the precise drawing from a copy) of those contours

- the 'compelling' spirituality (more strongly: 'constraining', 'coercive') of the music's 'sensuous' (that is, 'perceptible') configurations

\section{B. Incommensurability and imagination}

- the 'incommensurable' nature of Mahler's music (that is, the impossibility of its being measured or compared, in the sense of Hegelian absolute 'Geist', but also seeming to reinstate a Heideggerian notion of unmediated 'being' $)^{12}$

10 Ecce Homo, trans. Walter Kaufmann, in Basic Writings of Nietzsche (New York: The Modern Library, 1968): 756-57. Kaufmann's translation could itself be re-worked with respect to the phrase 'a thought flashes up, with necessity of form, without hesitation', and the translation of 'Unbedingtsein' as 'unconditionality' instead of 'absoluteness'. Man hört, man sucht nicht; man nimmt, - man fragt nicht, wer da gibt; wie ein Blitz leuchtete ein Gedanke auf, mit Notwendigkeit in der Form, ohne Zögern,-ich habe nie eine Wahl gehabt. ... Alles geschieht im höchsten Grade unfreiwillig, aber wie in einem Sturm von Freiheitsgefühl, von Unbedingtsein, von Macht, von Göttlichkeit.

11 See Max Paddison, Adorno's Aesthetics of Music (Cambridge: Cambridge University Press, 1993): 10, and Adorno, Modernism and Mass Culture. Essays on Critical Theory and Music (London: Kahn \& Averill, 1996): 68, for discussion of Adorno's critique of Heidegger.

12 Jean Paul's definition of wit as a form of deep critical understanding distinct from acumen, likewise involved the discovery of similarities between 'incommensurable magnitudes', and shares terminology and process with Adorno: 'a natural instinct 
- Mahler's symphonism as incarnated 'Idea', which evokes the vast religiophilosophical tradition of this indeterminate, irreducible term's use: from Plato's metaphysical essence of things, through the mediaeval Christian 'Idea' as the 'thought of God', to the Cartesian subjective 'Idea' as the mind's representation of a thing, Hegel's 'Idea' as objective truth and true being, and Schopenhauer's metaphysical division of 'Will' and 'Idea': 'Music is as immediate an objectification and copy of the whole will as the world itself is, indeed as the Ideas are' ${ }^{13}$; while all the other arts 'objectify the will only indirectly, in other words, by means of the Ideas', music is related to the Ideas in the sense of being an analogous direct manifestation of the noumenal in the phenomenal world, 'by no means ... a copy of the Ideas, but a copy of the will itself', ${ }^{14}$ that is, existing as Idea, rather than illustrating ideas (Schopenhauer and Adorno both shared a disdain for the programme music aesthetic).

- the privileging of an unsystematic 'contemplation' of music over rational argument and dogmatic, rule-bound 'Pharisaism' (a term whose Jewish connotations would bear further scrutiny)

- the acknowledgment in Mahler's music of a 'purely musical' residue that 'persists' (more strongly: 'makes its influence (or power) felt') and that cannot be interpreted structurally or emotionally, combined with the music's coercive 'spirituality', comes close to aping the sentiments of passages that Hanslick excised from later editions of his Vom musikalischen Schönen in order to distance himself from idealist philosophy (the omitted passages are shown in italics below):

If we now ask what is to be expressed with this tone-material, then the answer is: musical ideas. A musical idea brought to its appearance is already autonomous beauty; it is already an end in itself and in no way primarily a medium or material for the representation of feelings and thoughts, even if it is capable of possessing, at the same time, a high degree of symbolic significance in its reflection of the great laws of the world, which is something we find in all artistic beauty. Sounding forms in motion are the sole and exclusive content and object of music. ${ }^{15}$

enforces this similarity, and it is therefore more obvious and always instantaneous. The witty relationship is contemplated; acumen, on the contrary, which discovers and distinguishes new relationships between the established relationships of commensurable and similar magnitudes, obliges us to carry through a long series of ideas the light which in wit flashes by itself from the cloud', '§43. Wit, Acumen and Profundity', in Vorlesungen über Aesthetik (1804, rev. 1813 \& 1825), cited in Kathleen Wheeler, ed., German Aesthetic and Literary Criticism: The Romantic Ironists and Goethe (Cambridge: Cambridge University Press, 1984): 187; all but the first set of italics are mine.

13 Arthur Schopenhauer, The World as Will and Representation, trans. E.F.J. Payne, 2 vols (New York: Dover Publications, 1966): I: 257.

14 Schopenhauer, The World as Will and Representation: I: 257.

15 Eduard Hanslick, Vom Musikalisch-Schönen: Ein Beitrag zur Revision der Ästhetik in der Tonkunst, ed. Dietmar Strauss, 2 vols. (Mainz: Schott, 1990): I: 75, Eng. trans. from Mark Evan Bonds, 'Idealism and the Aesthetics of Instrumental Music at the Turn of the Nineteenth Century', Journal of the American Musicological Society, 50 (1997): 387-420; quotation, 415 .

Fragt es sich nun, was mit diesem Tonmaterial ausgedrückt werden soll, so lautet die Antwort: Musicalische Ideen. Eine vollständig zur Erscheinung gebrachte musikalische Idee aber ist bereits selbstständiges Schöne, ist Selbstzweck und keineswegs erst wieder 
This spiritual content also now unites in the disposition of the listener the beautiful in music with all other great and beautiful ideas. It is not merely and absolutely through its own intrinsic beauty that music affects the listener, but rather at the same time as a sounding image of the great motions of the universe. Through profound and secret connections to nature, the meaning of tones is elevated high above the tones themselves, allowing us to perceive at the same time the infinite in works of human talent. Because the elements of music - sound, tone, rhythm, loudness, softness - are to be found throughout the entire universe, so does one find anew in music the entire universe. ${ }^{16}$

In view of Adorno's seemingly conflicted conceptual framework and partly shared vocabulary, we may be justified in asking to what extent his thinking is covertly reliant on a nineteenth-century aesthetics which, like that of Hanslick, did not see idealism and formalism as incompatible, but rather, in a thoroughly Adornian apparent paradox, 'allowed instrumental music to retain its autonomy through an intrinsically musical, self-referential content without thereby being isolated from "extramusical" ideas", ${ }^{17}$ of Geist or the spiritual dimension. This was because 'idealism actually gave composers and critics unprecedented liberty to explicate instrumental works', not necessarily in a facile programmatic sense but in terms of music as '[a] reflection of an abstract ideal [which] ... is quite different from the representation of a specific object or event ${ }^{18}$ With comparatively little difficulty, through subtle shifts in terminological focus mediated by the act of translating a small excerpt of his text (but to an extent existing in the original German too), Adorno may be taken as more, or less, neo-idealist, empiricist, structuralist, protopostmodernist, formalist, absolutist, intuitive, rigorous, Hegelian, Schopenhauerian and so on, in approach - and all this even before attending to the sociological aspects of his theorizing. Such eclectic potential indeed aligns with the multiple influences acting on the formation of Adorno's thought, as examined at length by Max Paddison. ${ }^{19}$ Through the agency of language we are beginning to lose a coherent sense of the 'writerly' subject and the 'readerly' object, even though language is the only guarantor of either's viability. As Georg Lukács wrote in 1920:

as the objective world breaks down, so the Subject, too, becomes a fragment; only the ' $\mathrm{I}$ ' continues to exist, but its existence is then lost in the insubstantiality of its self-created world of ruins. Such subjectivity wants to give form to everything, and precisely for this reason succeeds only in mirroring a segment of the world. ${ }^{20}$

\footnotetext{
Mittel oder Material zur Darstellung von Gefühlen und Gedanken; wenn sie gleich in hohem Grad jene symbolische, die großen Weltgesetze wiederspiegelnde Bedeutsamkeit besitzen kann, welche wir in jedem Kunstschönen vorfinden. Tönend bewegte Formen sind einzig und allein Inhalt und Gegenstand der Musik.

16 Hanslick, Vom Musikalisch-Schönen, I: 171, Eng. trans. from Bonds, 'Idealism', 414-15. Dieser geistige Gehalt verbindet nun auch im Gemüth des Hörers das Schöne der Tonkunst mit allen andern großen und schönen Ideen. Ihm wirkt die Musik nicht blos und absolut durch ihre eigenste Schönheit, sondern zugleich als tönendes Abbild der großen Bewegungen im Weltall. Durch tiefe und geheime Naturbeziehungen steigert sich die Bedeutung der Töne hoch über sie selbst hinaus und läßt uns in dem Werke menschlichen Talents immer zugleich das Unendliche fühlen. Da die Elemente der Musik: Schall, Ton, Rhythmus, Stärke, Schwäche im ganzen Universum sich finden, so findet der Mensch wieder in der Musik das ganze Universum.

17 Bonds, 'Idealism', 417.

18 Bonds, 'Idealism', 416.

19 See Paddison, Adorno's Aesthetics of Music.

20 George Lukács, The Theory of the Novel, trans. Anna Bostock (London: Merlin Press, 1971): 53, quoted in Paddison, Adorno's Aesthetics of Music, 32.
} 
It is not my purpose here to attempt to answer the question posed above, or to pursue the categorization of Adorno much further. ${ }^{21}$ What I hope to have demonstrated, however, is that both Hanslick (through textual excision) and Adorno (through use of a vocabulary which lends itself to multiple readings and emphases of translation) open their ideas up to radical forms of conceptual re-contextualization and interpretative re-description. The extent to which Adorno desires or intends this for his text is difficult to determine, but what is more certain is that through the unstable conceptual and perceptual filter of language, the readerly 'object' (Mahler's music) also is 'involuntarily' and in a 'felt context of freedom' opened up for re-contextualization and re-description. Depending on one's reading of Adorno's linguistic-conceptual stance, this 'opening up' could take different forms. It might provide revelations of hitherto suppressed objective truths that Mahler's 'expressive intentions' and 'forcible spirituality' are seen always to have embodied. It might offer playful interpretations that, through 'contemplation', his music is allowed to inhabit. Or it might chart radical disruptions that the unassimilable 'purely musical residue', the 'incommensurable' and the unpredictable 'lightning flashes' that exceed their own 'existence', are made to yield in the critical process.

The uncertainty of these stances stems from a fundamental contradiction: in claiming that one can only gain perspective on Mahler by moving closer to him, 'entering into' him, and 'confronting the incommensurable' - and not by rational objectivity from an 'ostensibly fixed standpoint external' to the music - Adorno appears to reflect the problematizing of the subject-object relationship, as identified by Lukács, in the direction of their postmodern merging or categorial dissolution; or at least he offers a recognition of the twentieth-century collapse of this relationship and the need to deal with the situation. But, in contrast to the postmodern mantra of the object's surrender before the ever-closer all-powerful gaze of the subject, Adorno's ' $\mathrm{A}$ ' group of terms and expressions, listed above, reveals the counterbalancing fact that '[f]or Adorno, truth lies in the Object; it is not merely a projection of the thinking Subject'..$^{22}$ He therefore appears to want to have his objective cake and eat it. If this is the case, then the difficulty of Adorno's approach can be summed up in terms of his impossibly syncretic feat of maintaining an epistemological commensurability and a hermeneutic incommensurability as coexistent functions in his methodology. Preserving the antithesis of wanting to identify or measure what at the same time one treats as unidentifiable and unmeasurable, through processes that promise but defer identification and measurement, is only feasible for Adorno in his Mahler study by abjuring musical analysis and by adopting figurative vocabulary and language structures. More fundamentally, it is also tenable only by addressing Mahler's works in their unitary nature as objects whose constituent, 'purely musical', materials offer examples of the historical sedimentation of prior practices. Richly cultural though Adorno's readings are, they emerge from a supposed prioritizing of (originative) production over subsequent processes of distribution or reception, which are regarded as contingent because they 'endanger objective cognition' and because 'the effects of works of art ... cannot be satisfactorily determined by recourse to the recipients' ${ }^{23}$ Here we may have reached the limits

21 The author is currently involved in a large-scale linguistic, philosophical, aesthetic and cultural reassessment of Adorno's Mahler text, the fruits of which will be presented elsewhere.

22 Paddison, Adorno, Modernism and Mass Culture, 61.

23 'Theses on the Sociology of Art', trans. Brian Trench, Birmingham Working Papers in Cultural Studies 2 (1972): 121, quoted in Paddison, Adorno, Modernism and Mass Culture, 62. 
of Adorno's ingenious modernist artifice, for in one seminal case coinciding with the year in which his study appeared in an important third printing (1971), as well as generally in the years following its first publication (1960), and especially from around the time of Adorno's death (1969), Mahler's music began to enjoy a vigorous 'counterlife' ${ }^{24}$ of consumption and reception outside the conventional environments of the concert hall, the audio recording or the pedagogy of silent score study, where it has been subject to considerable re-contextualization and re-description as object, in ways which Adorno (and perhaps Mahler too) would probably have found deeply problematic. I am referring here to the world of the moving image. What kind of critical apparatus could effectively address the multifarious screen appropriations of Mahler?

Elsewhere I have documented 136 cases of the use of Mahler's music on screen dating from 1963 to $2008 .{ }^{25}$ In different ways, this 'counterlife' dismantles much of the critical approach set out in the excerpt from Adorno's book I have been discussing for the following reasons:

- whether or not Mahler is 'resistant to theorizing' and 'fails to acknowledge the choice between technique and imaginative content' becomes somewhat irrelevant in the face of the third-party requisitioning at work in screen media;

- the 'expressive intentions' have been reassigned to, if not re-fashioned for, whatever context or purpose the requisitioners wish;

- the need for and opportunity to 'move still closer to him' is more often than not prevented, even obviated, by the multi-media aesthetic;

- the transcending of 'categories of program and absolute music' is usually negated by the determined qualities of contingency with which most screen music is ascribed in order to communicate effectively and economically, to 'illustrate ideas' envisaged by the creators;

- taking the notion of a 'script prescribing its own interpretation' to extremes of commensurability, Mahler's music either has its assumed, rigidified meaning (often deriving from the cumulative effects of previous screen use, and the early model of Death in Venice) applied like quick-drying cement to a scene - such applications being prescribed for it by the narrative context of the screen work - or, more interestingly, the screen context alters or adds new layers to received interpretations of the music;

- resolutely adopting a 'fixed standpoint', much screen repertoire operates a protocol that does indeed 'tirelessly toy with clichés', especially that of the 'titanic late Romantic'.

24 I adopt this term from the title of the novel by Philip Roth, an extract from which heads this article. In the novel, a writer fictionalizes accounts of his family members' lives and in effect re-describes for them an alternative existence, in some cases more damaging, in others more enriching, than 'real' life. However, because of the manner of the novel's presentation, it is not always entirely clear which aspects of the narrated stories are to be taken as representative of historical 'reality' and which are to be taken as fabrications. Indeed the unproblematic acceptance of alternative 'realities' on the reader's part seems to be an essential ingredient of the novel's aesthetic.

25 Jeremy Barham, 'Plundering Cultural Archives and Transcending Diegetics: Mahler's Music as "Overscore"', Music and the Moving Image 3/1 (Spring 2010): 22-47, http://www.jstor.org/stable/10.5406/musimoviimag.3.1.0022. Recent additions to the list are Martin Scorsese's Shutter Island (2010), which uses the Piano Quartet movement in A minor, and Terrence Malick's The Tree of Life (2011) which uses the first movement of the First Symphony. 
All of this amounts to a multi-media 'mis-/re-pronouncement', '(re-)translation', or 're-description' of Mahler's music, a re-characterization rooted to a much greater extent in the pliable forces of reception than in the means of production.

In attempting to make fuller theoretical sense of these operations, I call on the pragmatist ideas of philosopher Richard Rorty, an advocate of one of the strongest modes of anti-foundationalist thinking - a mode that even Lawrence Kramer criticizes for 'subordinat[ing] the claims of reason to an extreme skeptical relativism'. ${ }^{26}$ In their shared resistance, Kramer, Jürgen Habermas, and more recently Giles Hooper - all explicit or implicit opponents of Rorty - have been exercised by the consequences of the latter's apparent anti-realism. Kramer continues: 'Without some appeal to standards of truth and falsehood, reality and illusion, reason and unreason, neither social institutions nor consensus beliefs can competently be criticized' ${ }^{27}$ Habermas writes:

Reaching understanding cannot function unless the participants refer to a single objective world, thereby stabilizing the intersubjectively shared public space with which everything that is merely subjective can be contrasted ... Without this supposition, everyday practices, which rest on the (in a certain sense) Platonic distinction between believing and knowing unreservedly, would come apart at the seams ... Rorty's naturalist strategy leads to a categorial leveling of distinctions of such a kind that our descriptions lose their sensitivity for differences that do make a difference in everyday practices. ${ }^{28}$

\section{The Habermasian Hooper concurs:}

[T]hat strong epistemological conviction which asserts that objects exist only by virtue of the particular discursive schema in which they receive their conceptual articulation ignores the dialectical point that such schemata themselves depend upon (the quite necessary presumption of) intersubjective agreement about a 'third-person' world which exists prior to and independently of them. ${ }^{29}$

However, Rorty has in fact never repudiated the existence of such a world. In moving to reject the Platonic, Cartesian and Kantian subject-object models and systems of representation, he acknowledges its presence but denies its capacity to determine responses or interpretations:

The causal independence of ... the text from the inquiring ... critic does not mean that she either can or should perform the impossible feat of stripping her chosen object bare of human concerns, seeing it as it is in itself, and then seeing how our beliefs measure up to it ... The pragmatists replace this idealist formulation with a wholehearted acceptance of the brute, inhuman, causal stubbornness of ... the text. But they think this should not be confused with, so to speak, an intentional stubbornness, an insistence on being described in a certain way, its own way. The object can, given a prior agreement on a language game, cause us to hold beliefs, but it cannot suggest beliefs for us to hold. ${ }^{30}$

26 Lawrence Kramer, Classical Music and Postmodern Knowledge (Berkeley: University of California Press, 1995): 7.

27 Classical Music and Postmodern Knowledge, 7.

28 On the Pragmatics of Communication (Cambridge, MA.: MIT Press, 1998): 359, 377.

29 'An Incomplete Project: Modernism, Formalism and the "Music Itself"', Music Analysis 23 (2004): 311-29; quotation, 320.

30 Objectivity, Relativism, and Truth (Cambridge: Cambridge University Press, 1991): 83. 
In his larger shift from a truth-seeking epistemology of commensurability to the conversational hermeneutics of the incommensurable, Rorty, unlike Adorno who appears to adhere to the mastery of the object (though perhaps as a cloak for the opposite), seeks to 'free us from the hold of an objective, mind-independent, Platonic world', ${ }^{31}$ to dismantle the age-old distinction between knowledge and opinion, and to follow thinkers (including Nietzsche) who 'avoid anything that smacks of philosophy as contemplation, as the attempt to see life steadily and see it whole, in order to insist on the sheer contingency of individual existence' ${ }^{32}$ Instead of inquiry or philosophy, and the beliefs thereby formulated, being construed as 'accurate or inaccurate representations of reality, or as candidates for unconditional validity', we should, according to Rorty, abandon representation as a viable concept and take inquiry as the 'quest for a coherent set of beliefs', ${ }^{33}$ and our beliefs to be 'action-tools for getting what we want'. ${ }^{34}$ In such a view, hermeneutics becomes an attempt to 'mediate between apparently incommensurable discourses and vocabularies', 35 a matter of 'reweaving our fabric of belief and desire, our attitudes towards various sentences of our language' ${ }^{36}$ The critical urge here to re-describe, as opposed to the metaphysical drive to demonstrate, is for Rorty encouraged by the reading of novels, such that he prefers to envisage a progressive contemporary culture as 'an increasingly poeticized one'. ${ }^{37}$ Indeed the root of intellectual progress for him is an imaginative, rather than inferential, 'inquiry as recontextualization', ${ }^{38}$ whereby " "creative misuses of language", ,39 "new, metaphorical use of old words ... the invention of neologisms ... and the colligation of hitherto unrelated texts ${ }^{40}$ provide opportunities for the re-evaluation of moral, political, aesthetic and cultural beliefs. It is here, then, that we can begin to locate an apposite framework for addressing the transplanting of Mahler's music into ostensibly alien screen contexts.

In light of my earlier critique of Adorno's text, and of Rorty's rejection of a priori transcendentals or absolutes on the grounds that ' $[t]$ there is no way to

31 Patricia Herzog, 'The Practical Wisdom of Beethoven's "Diabelli" Variations', The Musical Quarterly, 79 (1995), 35-54; quotation, 44.

32 Rorty, Contingency, Irony, Solidarity (Cambridge: Cambridge University Press, 1989): 26.

33 Objectivity, Relativism, and Truth, 101.

34 'Truth and Freedom: A Reply to Thomas McCarthy', Critical Inquiry 16 (1990), 633-43; quotation, 641.

35 R.J. Snell, Through a Glass Darkly: Bernard Lonergan and Richard Rorty on Knowing without a God's-Eye View (Milwaukee, WI: Marquette University Press, 2006): 63.

36 Rorty, 'From Logic to Language to Play: a Plenary Address to the InterAmerican Congress', Proceedings and Addresses of the American Philosophical Association, 59 (1986), 747-53; quotation, 750 .

37 Objectivity, Relativism, and Truth, 110.

38 From the title of a chapter in Objectivity, Relativism, and Truth, 93-110.

39 Frans Ruiter, 'Richard Rorty' in Postmodernism: The Key Figures, ed. Hans Bertens and Jospeh Natoli (Oxford: Blackwell, 2002): 279-286; quotation, 282.

${ }_{40}$ Rorty, Objectivity, Relativism, and Truth, 94. While the term 'colligation' has specific applications in the field of linguistics, describing connections between lexical and grammatical items of language, and in logic, describing the subsumption of isolated facts under a single hypothesis or explanation, Rorty here seems to be using it in the general sense of an act of lumping together objects (to 'colligate' literally means to 'bind together') such that each is experienced or 'read' in the context of the other. 
reach outside our language-game to an account of the relation between that language-game as scheme to "the world" as "content" ', ,1 I would like to ally this Rortyan (anti-)philosophical mode with consideration of the act of translation as re-contextualizing process. Theoretical approaches, going back at least to Friedrich Schleiermacher's 'On the Different Methods of Translating' (1813), have identified broadly opposing types of 'alienating' and 'integrating' translations, ${ }^{42}$ more recently termed 'overt' and 'covert'. ${ }^{43}$ As Juliane House suggests: 'Translation involves the movement of text across time and space, and whenever texts move, they also shift frames and discourse worlds', such that the text is recontextualized 'within a new set of relationships and culturally conditioned expectations'. ${ }^{4}$ 'Overt' translation aims to retain and communicate as much as possible of the original context in the new context: 'the ['overt'] translator puts target culture members in a position to observe and/or judge this text "from outside" ';5 "covert' translation conceals as much of the original context as possible so as to produce more of a 'second original' that fits seamlessly into the new context: 'It is the ['covert'] translator's express task to "betray" the original and as it were hide behind its transformation' ${ }^{46}$ Thus, though more 'faithful' to the original content, 'overt' translations remain deliberately 'alienated' from the target audience, while, in the attempt to retain a correspondence of function, 'covert' translations attempt to 'integrate' with the target audience through the application of cultural filters, and thus involve greater distancing from the original content.

The usage of Mahler's music on screen comprises in most cases a Rortyan 'colligation of hitherto unrelated texts', and a re-contextualization both of music and screen text that, in turn, often invites hermeneutic re-description in the attempt to 'mediate between apparently incommensurable discourses and vocabularies'. It is a practice that largely operates in the terms of 'overt' or 'covert' translation just outlined, and at times results in the substantial 'reweaving' of our 'fabric of belief' in relation to the fields of music and the moving image, or the specific Mahler and screen works, in ways that go beyond the merely playful or conformist. The first incommensurability to be dealt with is the inevitable and ubiquitous excerpting of Mahler's works that takes place in screen contexts. This commodifying of either the synecdochal part that stands for the whole or simply the isolated musical moment acts against conventional notions of the identity and integrity of the work, in favour of a snapshot aesthetic aligned with the demands of mass entertainment as industry. The differing implications of the fragmenting of substantial, multi-movement musical canvasses, the fragmenting of passages of extended continuity within these, and the fragmenting of what may already be fragmented in nature, are significant. In some cases the extract's absent surrounding musical context is replaced by the film's narrative context so that the music functions like any other

41 'From Logic to Language', 751.

42 See Schleiermacher, 'On the Different Methods of Translating', in Translating Literature: The German Tradition From Luther to Rosenzweig, ed. André Lefevere (Assen and Amsterdam: Van Gorcum, 1977): 67-89.

43 Juliane House, 'Text and Context in Translation', Journal of Pragmatics 38 (2006), 338-358; esp. 347.

44 'Text and Context in Translation', 347, 356.

45 'Text and Context in Translation', 348.

46 'Text and Context in Translation', 348. 
scoring cue, revealing in unexpected ways how pre-composed repertoire can quite easily be made to sound as if it had always been destined to serve as underscore. And yet at times this process also reflects different sets of beliefs back on to the excerpted music and its placing within its original context. An example of this is Moshe Mizrahi's War and Love (1985), set amidst the suffering of the Jewish ghettos in second-world-war Poland, which uses Mahler's First Symphony as its (historically emblematic) score. The gushingly emotional postwar reunion of the two young lovers towards the end of this film employs bars 464-515 of the final movement: the last appearance of the lyrically intense, appoggiatura-laden second theme in F major. Momentarily, Mahler's music assumes the mantle of perfectly synchronized underscore, as initial musical uncertainty matches physical distance and lack of recognition between the characters; at the point of the boy's sigh and recognition of his lost love from afar, the yearning oboe of bar 480 begins; at 'Etwas drängend' (bar 483) the boy starts to run as the strings take over with their series of urgent appoggiaturas; by the textural and melodic highpoint of bar 490, mutual recognition between boy and girl is achieved; at the più mosso and fff of bar 496 as the strings begin their final descent, she starts to run; and at the poco accel. of bar 499 they embrace amid incoherent sobs. This is more than a case of a piece of pre-existent music fitting a scene like a glove (the action may well have been choreographed to align with the musical moments). It serves to illuminate all the more the reading of this passage as emotional core of reconciliation in the movement: at its previous appearance, the thematic material was heard in D flat, a key far too distant to enact resolution. The $\mathrm{F}$ major of the passage used here recalls the gentle, nostalgic, pastorale trio of the Symphony's second movement (from bar 175) in the same key, and at the same time provides a more effective means of leading to the finale's subsequent closural triumph in D. Even without the surrounding musical contexts, this subtly inflects our understanding of the film's own imminent positive ending, also achieved after momentous struggle and pain.

At other times the fractured presentation of musical moments each 'fulfilling its musical function' but 'becoming more than its mere existence' seems to mirror the way in which Mahler's large-scale works are remembered: for their scattered points of melodic, harmonic, rhythmic, textural or timbral excess, transgression, negation or withdrawal. In Gregory Nava's El Norte (1983), after a torturous struggle through dank sewage pipes, two young Mayan peasant workers finally reach their goal of crossing the Mexican border undetected into America in the hope of starting a new life. Laid out before them is the 'glorious' spectacle of San Diego at night. Their guide tells them they will be in Los Angeles by the next day, whereupon the startling E major anticipatory breakthrough passage in the third movement of the Fourth Symphony (from bar 315) explodes into the diegesis, while a high-altitude panning shot surveys the cityscape as a concrete and steel utopia. One of the most shockingly unbidden moments in any Mahler work, which in retrospect we learn is a premonition of the Finale's heavenly utopia of pastoral innocence (and in his personal life, Mahler is known to have disliked urban environments ${ }^{47}$ ) collides here with an imaginary narrative prolepsis as the characters presumably contemplate their future opportunities to escape a life

47 See Herta Blaukopf, ed., Gustav Mahler Briefe, second edition (Vienna: Zsolnay, 1996): 158, and Norman Lebrecht, ed., Mahler Remembered (London: Faber \& Faber, 1987): 295, for such accounts relating to Mahler's experience of Berlin and New York. 
of servitude. Where one suggests the final locating of a spiritual Heimat, the other charts the pioneering move from pastoral oppression into the promise of the urban unknown. The film's enactment of re-birth recasts, and to some extent reverses, the Symphony's progression towards an unbearable lightness of being, part of Mahler's philosophical and spiritual quest in which, as for Ernst Bloch 'the true Genesis is not at the beginning, but at the end ... Once the [creative human] has grasped himself and that which is his ... so there will arise in the world something that shines into everyone's childhood, but where no one has yet been: Heimat'. ${ }^{48}$

In other instances, a screen practice that revels in shorthand associations only incites all the more strongly a longing for the whole source. As with certain 'overt' literary translations, the perpetrators of this form of re-contextualization might be said, as Goethe remarked, to 'advertise a half-veiled beauty as being very lovely: they arouse an irresistible desire for the original': ${ }^{49}$

This is particularly the case when filmmakers, whether interested in the poietic conditions of Mahler's music or not, engage in powerful acts of aesthetic counterpoint between music and image: an alienating effect akin to that of 'overt' literary translation. Parts of the 'Blicket auf!' aria from the Eighth Symphony's second movement setting of the conclusion of Faust Part II (Figs. 176-186) - a passage of seemingly unassailable sublimity - run like a silver thread through the work of the New German Cinema's most radical representative, Rainer Werner Fassbinder. Obsessed by what he declares to be the music that means most to him, he usually employs the excerpt at the most depraved, grotesque and pitiable points of his narratives: for example, Franz Biberkopf is scourged, sexually humiliated, tortured and defeated in various scenes of utter degradation in Berlin Alexanderplatz (1980) to this same music. Such moments seem to urge us to seek all the more avidly for an integration and wholeness of socio-political identity and cultural expression (all the more pressing given the subject matter of this screen series, and the chequered Austro-German reception history of Mahler's music), and to find completion precisely because of the fatalistic hopelessness and personal and historical fragmentation we are confronted with: 'The more fatalistic the film is, the more hopeful it is', as the director remarked. ${ }^{50}$

Whenever Mahler's music is used on screen, the possibilities exist that a) its historical and cultural baggage are central to that use; b) its historical and cultural baggage are, at least according to the intentions of the filmmakers, irrelevant to that use; and c) its historical and cultural baggage includes its screen appropriation: in other words its presence is acting as homage to, or parody of, a tradition established by its earlier screen use. Within these possibilities lie many ambiguities and incommensurables from which is woven a potentially highly complex interpretative fabric, not least because the agency of pre-existent music in screen works cannot be divorced from the variables of listener competency,

48 Das Prinzip Hoffnung (Frankfurt: Suhrkamp, 1959): 1628, cited and trans. in Bloch, Atheism in Christianity (London: Verso, 2009): xix.

49 Maximen und Reflexionen (1826), cited in Lefevere, Translating Literature, 39.

50 Norbert Sparrow, 'I let the Audience Feel and Think: An Interview with Rainer Werner Fassbinder', Cinéaste 8/2 (1977), 20. For fuller discussion of Fassbinder's use of this music see Jeremy Barham, "“A Time of Gifts": Mahler's Eighth, Fassbinder's Cinema, and Musical Politics' in Mahler's Eighth Symphony: Studien zur Wertungsforschung, ed. Peter Revers (Vienna and London: Universal Edition, forthcoming, 2011). 
experience and perceptual/emotional response. At play in many instances are factors of, for example:

- Mahler's presumed authorial, personal and historical identity

- The wider socio-political contexts with which he, his music and its reception have been associated, including the modish character of his 1960s renaissance and subsequent 'boom' years

- The 'grand narrative' supplied by the long shadow of Visconti's Death in Venice, itself complicated by Mann's temporarily hidden connection between Aschenbach and Mahler, by Dirk Bogarde's physical similarity to Mahler, by distasteful connotations of paedophilia, by demotic re-readings of the film's worship of beauty as emblems of warped sexuality, homosexuality or male effeminacy/effeteness, by a manner of film-making using extremely long takes that fetishize the male 'gaze' and attenuate narrative momentum, and by a general ponderousness that opens itself up for parody

- The widespread imitation of elements of Mahler's musical idiom by generations of specialist screen composers including Max Steiner, Erich Korngold, Hugo Riesenfeld, Bernard Herrmann and John Williams (from melodic gestures and thematic variant technique, through instrumental effects, to a provisionalized, moment-to-moment approach to structural change)

- The possibility that the re-contextualizing act of translating Mahler's music into a screen environment calls for some kind of subtle or even radical Rortyan re-description of the music's received meanings

I would like to conclude by focusing on examples that illustrate the third and fifth of these factors. The 1994 film Venus in Furs (an adaptation of the 1870 Sacher-Masoch novella, directed by Maartje Seyferth and Victor Nieuwenhuijs) employs the Adagietto from the Fifth Symphony during an erotic sadomasochistic encounter between the male and female characters in the story within the story. The music sounds only when there is either the intimation, or the actual instigation, of 'normal' sexual behaviour: while the woman's abortive whipping of the man takes place without music, her expressions of emotional resistance to the practice, her unwillingness to continue, and the man's subsequent exquisitely slow coverage of the entire length of her naked body with delicate kisses filmed in extreme close-up, all occur as we hear approximately the first four minutes of the movement. The shift to this scene from the 'real' world of the main characters (played by the same actors) had also been accompanied by the onset of the music, and by a voice-over indicating the male character's growing obsession with the woman - a case not of love but of 'physical enslavement', as it is described.

In 1971, Visconti's Death in Venice greatly enhanced a process of re-description of the Adagietto from Mahler's Fifth Symphony that had begun during the postwar years in the concert hall, recording and other contexts. ${ }^{51}$ In repeatedly allying the piece so vividly with narrative contexts of artistic and physical decay, and ultimately with a prolonged scene in which death and a - perhaps misguided, perhaps sexually perverted - pathetic longing for unattainable 'beauty' are mingled, Visconti's film helped cement both a fashionable performance tradition

51 Among the slowest performances of the Adagietto (at c.15 minutes) is Hermann Scherchen's with the Orchestre National de l'ORTF (available on Harmonia Mundi), recorded in 1965 and thus pre-dating Visconti's film. 
depending on extreme slowness, and a set of assumptions about the 'intrinsic' meaning of the music. The mournful, death-related assumptions had previously been substantially underpinned by Leonard Bernstein's approach to Mahler, and more specifically by his conducting of the Adagietto at the funeral of Robert Kennedy in New York, in 1968. ${ }^{52}$ Venus in Furs both draws on and subverts these traditions. In the former case, it adopts the music's inherited association with sexual desire in general, and with a putatively 'unhealthy' aspect of sexual activity in particular. It allies the music with the larger movement of Austro-German late-nineteenth-century cultural decadence and eroticism in which Leopold von Sacher-Masoch (whose novella was based on his own experiences acting as a 'slave' to his mistress while on a train journey to Venice) was a prominent figure, but which was largely anathema to Mahler. In the latter case, the specificity of the use of the Adagietto in the scene described above distances the music from connections with perceived sexual perversion; indeed, on the contrary, it serves to infuse 'normal' sexual behaviour with elevated, high-art qualities. In scholarly and historical terms, Mahler's music has rarely, if ever, been interpreted in erotic contexts. Blending with biographical accounts of the composer's profoundly serious, ascetic dedication to art and to elemental questions of human existence, and of Alma Schindler's declaration that Mahler filled her with 'the holiest feelings' as opposed to the carnal passion of her previous lover Zemlinsky, ${ }^{53}$ readings of his music, often in resistance to the 'intentional fallacy', have generally eschewed gendered, eroticized perspectives. ${ }^{54}$ Though the consultation with Freud in 1910 came about as a result of deteriorating relations with Alma, of which some form of supposed male sexual dysfunction was a part, Mahler was dismissive of psychoanalysis's attribution of sexual causes for all such problems. ${ }^{55}$ Nevertheless, it has also been suggested that, years before this, Mahler composed the Adagietto at least partly in response to his burgeoning emotional and physical attachment to Alma in the early months of their relationship. ${ }^{56}$ At the very least, Venus in Furs, affected exercise in glorified soft porn though it may be, brings together sex, gendered discourse and Mahler - fields of inquiry that remain academically incommensurate whilst having something of a history in popular culture - into novel configurations. Unlike other films, which have simply aped or satirized the Visconti legacy (Permanent Record (1988), Death in Brunswick (1990), Scorchers (1991), Lorenzo's Oil (1992), Stiff Upper Lips (1999), Before Night Falls (2000), Paragraph 175 (2000), and Timecode (2000)), this film partially resists the 'covert' translation process by which others have presumed a universally culturally understood, transferable

52 Bernstein also conducted Mahler's Second Symphony in the 'John F. Kennedy Memorial concert' televised two days after the assassination in 1963.

53 See Alma Mahler-Werfel. Diaries 1898-1902, trans. and ed. Antony Beaumont (London: Faber \& Faber, 1998): 464.

54 A rare exception is Peter Franklin's 'A Soldier's Sweetheart's Mother's Tale? Mahler's Gendered Musical Discourse' in Mahler and His World, ed. Karen Painter (Princeton: Princeton University Press, 2002): 111-25. The most extensive psychoanalytically orientated study of Mahler, Stuart Feder's Gustav Mahler: A Life in Crisis (New Haven: Yale University Press, 2004), tends to set Mahler as chaste, deeply spiritual sufferer against Alma as frivolous and destructive pleasure-seeker.

55 See Henry-Louis de La Grange, Gustav Mahler, vol. 4, A New Life Cut Short (1907-1911) (Oxford: Oxford University Press, 2008): 884.

56 See Gilbert Kaplan, 'Adagietto: "From Mahler with Love"', in Perspectives on Gustav Mahler, 379-400. Alma gives candid accounts of her early sexual activity with Mahler in her diaries; see Diaries 1898-1902, 466-67. 
meaning adopted from prior traditions of semantic solidification of a seamless 'second original', in favour of the alienating possibilities of 'overt' translation in which the accepted norms of an inherited and shared cultural tradition are questioned, and more fundamental re-description of an original is invited.

Elsewhere I have discussed the use of the first movement of the Third Symphony in Peter Watkins's The Gladiators (1969), a film that addresses the futility of war and the oppression of individualism by militaristic states, in the context of futuristic, staged war games. ${ }^{57}$ By juxtaposing the movement's march sections (bars 799-857, 799-845 (omitting 808-815), and 225-297, 315-363) which in the structural context of the music offer two extended attempts at collectivity and progress, a marshalling of forces towards a shared goal - with either military preening and pomposity, bitterly cynical accounts of the human cost of war, or scenes of violence perpetrated by gas-masked, baton-wielding officers against two individual escapees (presented in a series of monochrome stills, with cut-aways to a smug photo shoot of officious generals), the film encourages a radical re-description of Mahler's movement. Viewing the beatings are a selection of military leaders from across the world who defend their actions:

(Italy) 'Sometimes we must do things like this, people not like, otherwise we look afraid'

(East Germany) 'The aggressive tone of West-German imperialists forces the German Democratic Republic to be strong, to defend the achievements of socialism. Only socialism is a guarantee of world freedom'

(France) 'Yes, it is certainly very true'

(India) 'India cannot isolate herself. She has to live in the community of nations. Under the impact of these inevitable circumstances, therefore, outside of our control, we sometimes have to twist matters in conflict with our conscience'

(Nigeria) 'Leniency always has its place, gentlemen, but as a young nation, Nigeria has to recognize the need for strength and discipline'

Multi-national, top-down collectivity is thus implicitly pilloried, in the film, for its suppression of the individual; and this sentiment very brazenly reflects back on the Mahler march underscoring events here. This march can no longer be taken at face value as a relentlessly positive, forward-moving, rallying cry of the masses. It has been cynically undercut, in the manner of the militaristic satire that pervades, for example, the feature film $\mathrm{M}^{*} \mathrm{~A}{ }^{*} \mathrm{~S} H$ (which was contemporaneous with The Gladiators) and its later spin-off television series, except that this scene in Watkins's film lacks the humorous edge. If such internationally sponsored control is held to be incapable of providing an adequate solution to the kind of problems of expansionist individual nation-states that had triggered two world wars, then it is perhaps not surprising that in another political era Mahler's experience of socio-cultural and geographical nomadism, within an increasingly fragile multi-national Habsburg Empire, would find expression in the ultimate catastrophic destruction of an ostensibly stable communal march, not once but twice in this movement (bars 362-367 and 857-863). The filmic re-contextualization brings out hitherto submerged possibilities of musical re-description, which then prove very hard to repress.

In his essay 'The Pragmatist's Progress', Rorty distances himself from the structuralist dependence on 'textual mechanisms', and from the post-structuralist

57 Barham, 'Plundering Cultural Archives'. 
deconstructing of 'metaphysical hierarchies' ${ }^{58}$ He has also found no meaningful use for the notion of post-modernism. ${ }^{59}$ Instead he describes interpreting texts as 'reading them in the light of other texts, people, obsessions, bits of information ... and then seeing what happens' ${ }^{60}$ Such an apparently undisciplined approach might seem surprising coming from a philosopher steeped in the analytical tradition. But presumably Rorty at some point came face to face with his own incommensurable: the realization that after decades spent studying centuries of systematic thinkers and epistemological discourses, he was still no nearer to an adequate conceptual representation of reality. This is why he devoted himself to replacing a failed epistemological commensurability with an experimental and imaginative hermeneutic incommensurability that has very close affinities with the sentiments of the Roth quotation at the head of this essay. Rorty writes:

Unmethodical criticism of the sort which one occasionally wants to call 'inspired' is the result of an encounter with an author, character, plot, stanza, line or archaic torso which has made a difference to the critic's conception of who she is, what she is good for, what she wants to do with herself: an encounter which has rearranged her priorities and purposes. Such criticism uses the author or text not as a specimen reiterating a type but as an occasion for changing a previously told story. ${ }^{61}$

This study has in its own way offered colligations, not just of Mahler and screen, but also, as part of its critical frame, of Micznik and Adorno, Jephcott and Adorno, Mahler and Adorno, Adorno and various philosophical traditions, and Rorty and Kramer/Habermas/Hooper. The remaining, perhaps larger, colligation is that of Adorno and Rorty, thinkers whose ostensible incommensurability of concerns and approach masks the shared virtuosic conceptual balancing acts through which both of them achieve new provisional critical syntheses, and through which they indefinitely prolong the desire for re-description (including mutually driven re-descriptions of their own works) in the imaginative contingency of inspiration and conditioning mediation of language. Through Mahler's own processes of creative inspiration (seeming to be dictated to by higher powers, or being handed the key to unlocking a symphonic finale like a sudden flash of lightning) similar re-descriptions have been invited not only in the language of the symphony, song, and song-symphony, but also in the re-translated language and semantics of his music's wider, refracted cultural dissemination, permeation and engagement: its proliferating 'counterlife'.

58 In Umberto Eco, Richard Rorty, Jonathan Culler and Christine Brooke-Rose, Interpretation and Overinterpretation, ed. Stefan Collini (Cambridge: Cambridge University Press, 1992): 89-108; quotations, 105.

59 In interview, Rorty has said: 'I've always found it a useless term. I wouldn't know how to define it or even how to use it ... As far as the philosophical ideas go, the ideas that are called postmodern seem to me to have been perfectly well formulated by about 1910, the time of the death of William James, so postmodernsim doesn't seem a very appropriate term'. 'Of Beauty and Consolation' (http://video.google.com/videoplay?docid $=6148968394915050958 \#)$, accessed January 2011.

60 Eco, Rorty, Culler and Brooke-Rose, Interpretation and Overinterpretation, 105.

61 Eco, Rorty, Culler and Brooke-Rose, Interpretation and Overinterpretation, 107. 